\title{
PRELIMINARY EXPERIMENTS ON THE FORMATION OF ELONGATED AIR BUBBLES IN GLAGIER ICE BY STRESS
}

\author{
By Masayoshi Nakawo and Gorow Wakahama \\ (Institute of Low Temperature Science, Hokkaido University, Sapporo, Japan o6o)
}

\begin{abstract}
Biaxial compression tests on glacier ice with bubbles revealed that elongated air bubbles were developed with long axes in the direction of free expansion. The elongated bubbles were not only derived from spherical bubbles but also created by the healing of cracks that were developed during compression. Formation of elongated bubbles and foliations in natural glacier ice are discussed here in the light of results obtained experimentally.

RÉsumé. Expériences préliminaires sur la formation de bulles de l'air allongées dans la glace de glacier sous contrainte. Des essais de compression biaxiale sur la glace de glacier contenant des bulles montrent que des bulles de l'air allongées se développent avec l'axe long dans le sens de l'expansion libre. Les bulles allongées ne se forment pas seulement à partir de bulles sphériques, mais aussi par l'inclusion de fissures formées au cours de la compression. Les auteurs discute de la formation des bulles allongées et de la foliation dans la glace de glacier naturelle à la lumière des résultats obtenus expérimentalement.

Zusammenfassung. Vorläufige Versuche zur Bildung verlängerter Luftblasen in Gletschereis durch Druck. Zweiachsige Druckversuche an blasenhaltigem Gletschereis zeigten, dass sich verlängerte Luftblasen mit Längsachsen in Richtung der freien Ausdehnung entwickelten. Die verlängerten Blasen entstanden nicht nur aus sphärischen, sondern auch aus Sprüngen, die bei der Kompression auftraten. Die Bildung verlängerter Blasen und Bänderungen in natürlichem Gletschereis wird im Lichte dieser experimentell gewonnenen Ergebnisse diskutiert.
\end{abstract}

\section{INTRODUCTION}

Many glaciologists (Kizaki, I969; Tanaka, I972; Wakahama, r974; Nakawo and Tanaka, 1974; Nakawo and Wakahama, 1974; Matsuda and others, 1976; Russell-Head and Budd, 1979) have reported that elongated air bubbles that are almost cylindrical in shape, coexist with many spherical bubbles in ice near the termini of glaciers. It has been reported also that the direction of bubble elongation was, in many cases, almost parallel to the flow direction and to the foliation in glacier ice. Hudleston (1977) argued that spherical bubbles in ice were elongated passively by a strong shear stress.

Nakawo (1976) observed in a debris-covered glacier in the Nepal Himalaya that elongated bubbles were present not only near the active terminus but also over a wide area extending from an ice fall to the terminus. Their orientation near the terminus was consistent with those mentioned in many other reports. At the base of the ice fall, however, it was found that the elongated bubbles were almost vertical in orientation.

The purpose of the present paper is to show how elongated air bubbles are created in ice that is subjected to biaxial compression and hence to explain the observed distribution and orientation of elongated bubbles in natural glacier ice.

\section{EXPERIMENTAL RESULTS AND DISGUSSION}

\section{Apparatus and specimens}

Figure I shows the biaxial compression apparatus used in the experiments. Reference axes for a specimen are labelled as follows: axis $x$ is the direction of main compression, axis $y$ is the direction of free expansion, and axis $z$ is the direction of lateral constraint.

An ice block, containing only spherical bubbles, was cut out from core samples taken from Heitō Glacier, East Antarctica (Nakawo and Tanaka, 1974). Thin rectangular specimens, $4 \mathrm{~cm} \times 4 \mathrm{~cm}$ in the $x y$ plane and $0.4 \mathrm{~cm}$ in the $z$ direction, were prepared from this block for the experiments.

The experiments were performed in a temperature range of $-\mathrm{I}$ to $-2{ }^{\circ} \mathrm{C}$. The cross-head speed of the testing machine applying the compressive load was $1 \mathrm{O}^{-4}$ to $1 \mathrm{O}^{-5} \mathrm{~cm} / \mathrm{s}$. 


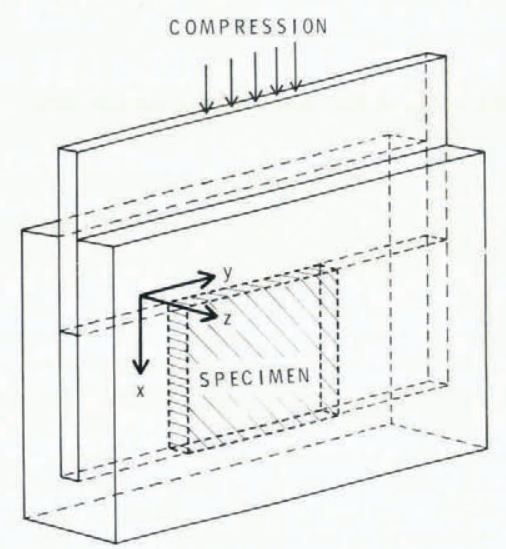

Fig. . Experimental apparatus.

\section{Bubble elongation and cracks}

As the specimen was compressed, the spherical bubbles began to elongate in the $y$ direction with a deviation of $\pm 30^{\circ}$. This deviation seems to be dependent on the optic-axis orientation of the crystals in which air bubbles were contained.

Two types of crack were observed during the experiments. One type appeared at the first stage of the compression at fast cross-head speeds $\left(c .10^{-4} \mathrm{~cm} / \mathrm{s}\right)$. These were initiated at an air bubble, without any preferred direction. The other type consisted of rows of small cracks in the $y$ direction with deviation of $\pm 30^{\circ}$. The long axis of each crack was in the direction of the row, i.e. in the $y$ direction with a deviation of $\pm 30^{\circ}$. The perpendicular to the plane of the cracks tended to be in the direction of the compression. These cracks became visible gradually as compression proceeded (at a later stage than the former type). They were observed in all of the experiments.

The deviation in orientation both of the elongated bubbles and of the latter type of cracks decreased with increasing strain. The orientation became almost parallel to the $y$ direction $\left( \pm 10^{\circ}\right)$ when $40 \%$ strain was reached. Similar results were reported by Minoshima (unpublished) when a uniaxial tension was applied to an artificially-made bubbly ice. Bubbles were elongated in the direction of application of the tension as the deformation proceeded.

Figure 2 shows an example of a specimen before and after compression (the former type of cracking did not occur in this sample). It may be seen that most of the spherical bubbles were laterally elongated. The average axial ratio of the elongated bubbles was $3.8 \pm 0.9$, without discernible dependence on bubble size. This value of the axial ratio was significantly larger than that of the strain ellipse for the deformed specimen, which was 2.2. Kamb (1972) also reported that the degree of bubble flattening observed in his torsional experiments of snow-ice was somewhat larger than that expected from the bulk strain of the specimen.

Gay (1968) developed a theory on the discrepancy between the strain ellipse of a deformed material and the shape change of foreign material embedded previously in the host material, assuming that both materials were Newtonian fluids having different viscosities. For an initially circular particle,

$$
\ln A=\frac{5}{2 R+3} \ln B
$$

where, $A$ and $B$ are axial ratios of strain ellipses of embedded material and host material respectively, and $R$ is the viscosity ratio of the materials. In this equation, taking the value of 
(a)

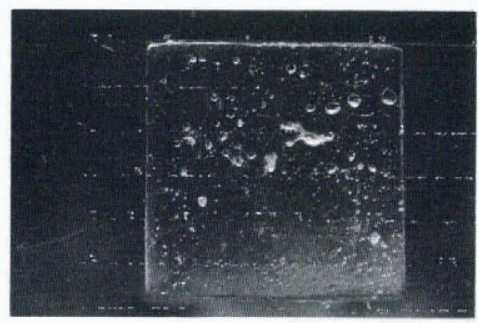

(b)

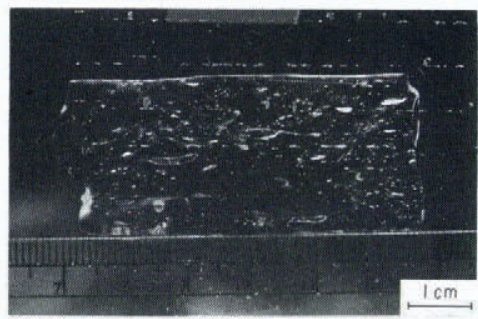

Fig. 2. A specimen (a) before and (b) after compression.

viscosity of air as zero (i.e. $R=0$ ), and the value of axial ratio of strain ellipse of ice as 2.2, then the axial ratio of the elongated bubble comes to 3.7 . This value agrees well with the measured value of 3.8 . This agreement is rather surprising since ice is not a Newtonian fluid but a crystalline material.

Figure 3 shows one of the second type of elliptical cracks developed in the specimen. The surface of the crack was normal to the compressive axis and the long axis was almost parallel to the direction of free expansion ( $y$-axis). It appeared that some of the elliptical cracks started from small spherical air bubbles, but others were initiated spontaneously within crystals. It was difficult, however, to identify clearly the origin of individual cracks.

The cracks tended to be concentrated on parallel planes normal to the compressive axis, forming a similar overall pattern to the foliation found in natural glacier ice. According to biaxial compression experiments of previously dyed ice samples made by H. Fushimi (private communication), a foliated pattern was found to be normal to the compressive axis and the dye concentrated in the foliations. These experimental observations would support the suggestion that foliations were formed vertically normal to the flow direction at the base of an ice fall, as found by Nakawo (1976) in the Nepal Himalaya, owing to the strong compression in the direction of flow. It was speculated also by Allen and others (1960) from the foliation

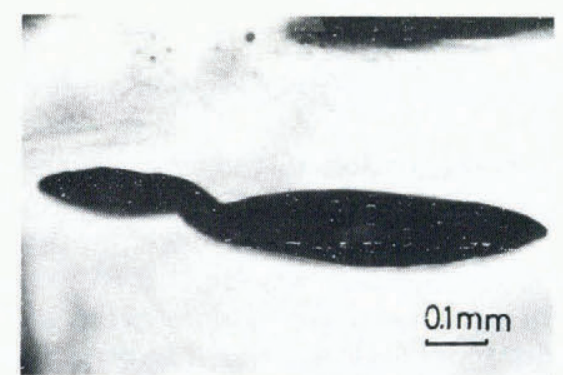

Fig. 3. The second type of cracks. Main compression axis is vertical in direction. 
pattern in the lower part of the tongue of Blue Glacier that vertical foliations form normal to the flow direction at the base of an ice fall.

In the present experiment after reaching about $40 \%$ compression, the sample was subjected to isothermal annealing for about one day at $0^{\circ} \mathrm{C}$. As seen in Figure 4 , cracks created by the compression changed into tabular bubbles and some of the cracks healed. The axial ratio of elongated or tabular bubbles thus formed was much larger than that of the elongated bubbles formed during compression. Simultaneously many small spherical bubbles appeared, forming a series of rows as shown in Figure 5. The formation of rows of small bubbles is thought to be due to the original cracks. Muguruma and others (1966) have reported the formation of rows of cavities or continuous cracks within a single crystal of ice subjected to non-basal glide. It is considered, however, that the mechanism of the formation of rows of small bubbles during annealing is different from that for the non-basal glide experiments.

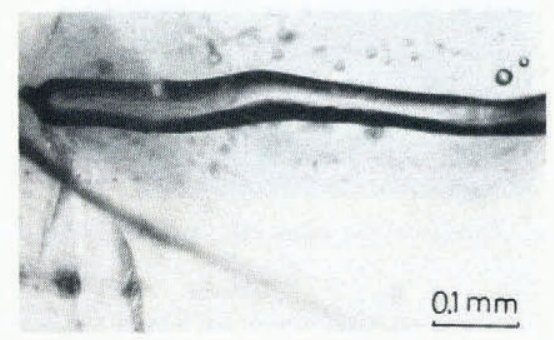

Fig. 4. Elongated bubbles formed after the thermal annealing. Compression axis is vertical in direction.

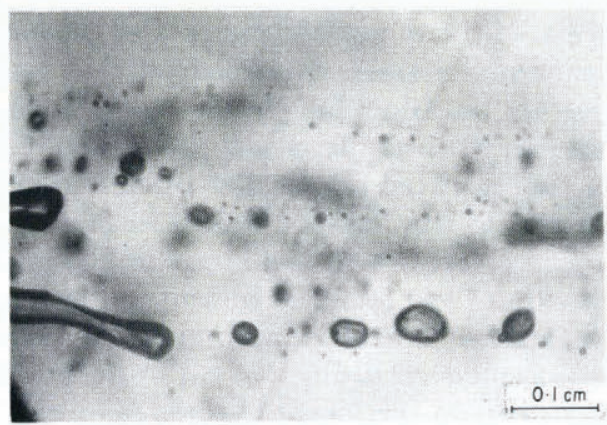

Fig. 5. Rows of small bubbles. Compression axis is vertical.

\section{VARIATION IN AXIAL RATIO OF THE BUBBLES}

Elongated bubbles found in glacier ice have a range of axial ratios although the orientation of their long axes is relatively constant. In a biaxial compressive experiment, the elongated bubbles were almost parallel in orientation to the tensile direction (the $y$ direction), which would correspond to the vertical direction at the base of the ice fall.

Variation in axial ratio was also observed in the experiments. For elongated bubbles developed from spherical ones, the variation was established to some extent (ranging from 2.4 to 5. I). This may be due to the variation of the angle between the flow direction and crystallographic orientation of individual host crystals of each bubble, although the orientation of the crystals also changed with time. Elongated or tabular bubbles formed from the healing of 
cracks had a much larger axial ratio than those formed from elongated bubbles created by mechanical deformation. The simultaneous occurrence of these two mechanisms could cause a large variation in the amount of elongation in natural glacier ice.

Elongated bubbles, once formed, could be further elongated by subsequent deformation. The elongation rate would be dependent on the ratio of the primary and secondary axes and the local strain. Since axial ratio of an elongated bubble formed by mechanical deformation in this experiment seemed to have no dependence on bubble size, the rate of the further elongation would also be independent of size.

Surface tension, however, caused morphological changes in the tabular bubbles during long periods, tending to make them more spherical in shape. The rate at which individual bubbles return to a spherical shape depends on their volume (Nakawo, I977). If the initial axial ratio is the same, a large bubble changes into a spherical one at slower rate than a smaller one. This would explain the condition found by Hudleston (1977) that larger bubbles had a greater axial ratio than smaller ones in natural glacier ice.

Because of the counteracting effect of elongation and a return to spherical shape, there could be a critical size of spherical air bubbles, below which no elongation occurs. This condition could depend on the local strain-rate and temperature. It was found in several glaciers that most of the spherical bubbles that coexist with elongated bubbles were comparatively small in volume (Hudleston, I977; Nakawo, in preparation).

When explaining the tendency for smaller bubbles to be more spherical, one should also take into account the phenomenon that tabular bubbles having a small diameter sometimes split into several fine spherical bubbles as the result of reduction of the surface energy (Maeno, I967; Nakawo, 1977).

\section{Concluding Notes}

Specimens of glacier ice, which contained only spherical bubbles, were compressed biaxially to investigate the mechanism of formation of elongated bubbles. Two kinds of elongated bubbles were produced. One was formed from originally existing spherical bubbles and the other from cracks developed by the compression. Both showed similar characteristics to the elongated bubbles found in natural glacier ice.

The experimental results provided an explanation of the relation between bubble orientation in ice and glacier movement. The vertically oriented elongated bubbles found at the base of the ice fall of the glacier studied in the Nepal Himalayas, would be created by the strong longitudinal compression. Once formed, they were deformed subsequently in proportion to the increasing strain in ice (Nakawo, r979).

The experimental results suggested that biaxial compression could also cause the foliation in glaciers. This would explain its vertical orientation normal to the flow at the base of an ice fall. Once formed, the foliation would be deformed passively owing to differential movements within glacier ice (Allen and others, I96o; Hooke and Hudleston, I 978; Nakawo, r 979).

\section{Acknowledgements}

The authors are grateful to Mr H. Narita of the Institute of Low Temperature Science, Hokkaido University, for the use of his straining device. They are also indebted to Professor D. Kuroiwa of the Institute, and Dr L. W. Gold of the Division of Building Research, National Research Council of Canada, for critical reading of the manuscript and for giving many valuable comments. Thanks are extended to the members of the Applied Physics Section of the Institute for helpful discussions.

MS. received I October 1979 and in revised form 27 November 1979 


\section{REFERENCES}

Allen, C. R., and others. I96o. Structure of the lower Blue Glacier, Washington, [by] C. R. Allen, W. B. Kamb, M. F. Meier, and R. P. Sharp. Journal of Geology, Vol. 68, No. 6, p. 6oI-25.

Gay, N. C. 1968. Pure shear and simple shear deformation of inhomogeneous viscous fluids. 1. Theory. Tectonophysics, Vol. 5, No. 3, p. $211-34$.

Hooke, R. L., and Hudleston, P. J. 1978. Origin of foliation in glaciers. Journal of Glaciology, Vol. 20, No. 83, p. $285-99$.

Hudleston, P. J. 1977. Progressive deformation and development of fabric across zones of shear in glacial ice. (In Saxena, S., and Bhattacharji, S., ed. Energetics of geological processes. New York, Springer-Verlag, p. 1 $21-50$.

Kamb, W. B. 1972. Experimental recrystallization of ice under stress. (In Heard, H. C., and others, ed. Flow and fracture of rocks, edited by H. C. Heard, I. Y. Borg, N. L. Carter, and C. B. Raleigh. Washington, D.C., American Geophysical Union, p. 2 I I-4I. (Geophysical Monograph 16.))

Kizaki, K. 1969. Ice-fabric study of the Mawson region, East Antarctica. Fournal of Glaciology, Vol. 8, No. 53, p. $253-76$.

Maeno, N. 1967. Air bubble formation in ice crystals. (In Oura, H., ed. Physics of snow and ice: international conference on low temperature science. ... I966. ... Proceedings, Vol. I, Pt. I. [Sapporo], Institute of Low Temperature Science, Hokkaido University, p. 207-18.)

Matsuda, M., and others. 1976. Nankyoku hyōshōhyō no sōshō [Twinning of ice from Antarctic ice sheet]. [By] M. Matsuda, G. Wakahama, W. F. Budd. Teion-kagaku: Low Temperature Science, Ser. A, [No.] 34, p. $163-71$.

Minoshima, K. Unpublished. Sosei-henkei ni yoru kōri-kesshō chū no kihō no kyodō [The behaviour of air bubbles due to plastic deformation in ice crystals]. [B.Eng. thesis, Hokkaido University, 1975.]

Muguruma, J., and others. 1966. Void formation by non-basal glide in ice single crystals, by J. Muguruma, S. Mae, and A. Higashi. Philosophical Magazine, Eighth Ser., Vol. 13, No. 123, p. 625-29.

Nakawo [i.e. Nakao], M. 1976. Bubble pattern of a glacier near Tukche Peak in Hidden Valley, Mukut Himal. Seppyō, Vol. 38, Special Issue, p. 44-49.

Nakawo [i.e. Nakao], M. 1977. Shinchō-kihō ni chakumoku shita hyōga kōzō to ryūdō no kenkyū [Studies on structure and flow of a glacier related to elongated bubbles]. Teion-kagaku: Low Temperature Science, Ser. A, [No.] 35, p. I 79-219.

Nakawo [i.e. Nakao], M. 1979. Deduction of glacier flow from the distribution of elongated bubbles. Fournal of Glaciology, Vol. 24, No. 9o, p. 457-67.

Nakawo [i.e. Nakao], M., and Tanaka, S. I974. Tō nankyoku, heitō hyōga no bōringu koā no kesshō shujiku hōi bunpu ni tsuite [On the orientational distribution of $c$-axis of ice crystals of core samples]. (In Kuroiwa, D., ed. Kyokuchi hyōshōhyō no butsuriteki kagakuteki kenkyū [Physical and chemical studies in ices from glaciers and ice sheets]. Monbushō Kagaku Kenpi Sōgō Kenkyū (A). Hokukusho, [1973], p. ro9-13.)

Nakawo [i.e. Nakao], M., and Wakahama, G. 1974. Arasuka-shū Makkōru-hyōga chūryūiki no bōringu koā no kaiseki [Fabric studies of glacier ice obtained from McCall Glacier, Alaska]. (In Kuroiwa, D., ed. Kyokuchi hyōshōhyō no butsuriteki kagakuteki kenkyū [Physical and chemical studies in ices from glaciers and ice sheets]. Monbushō Kagaku Kenpi Sōgō Kenkyū (A). Hokukusho, [1973], p. I 2 I-25.)

Russell-Head, D. S., and Budd, W. F. 1979. Ice-sheet flow properties derived from bore-hole shear measurements combined with ice-core studies. Fournal of Glaciology, Vol. 24, No. 90, p. 1 1 7-30.

Tanaka, H. 1972. On preferred orientation of glaciers and experimentally deformed ice. Fournal of the Geological Society of Japan, Vol. 78, No. 12, p. 659-75.

Wakahama, G. I974. Nankyoku Amerii-dana hyō, Uirukusu-hyōkyū oyobi Forugā-misaki no shinsōhyō no kōzō soshiki ni tsuite [On the structure and texture of deep ice cores from Amery Ice Shelf, Wilkes Dome, and Cape Folger, Antarctica]. (In Kuroiwa, D., ed. Kyokuchi hyōshōhyō no butsuriteki kagakuteki kenkyū [Physical and chemical studies in ices from glaciers and ice sheets]. Monbushō Kagaku Kenpi Sōgō Kenkyü (A). Hokukusho, [1973], p. 99-108.) 